\title{
Strategi Pengembangan Wisata Kesehatan melalui Pemberdayaan Kelompok Sadar Wisata pada Masyarakat Kepulauan (Studi Kasus: Pulau Giliyang Kecamatan Dungkek Kabupaten Sumenep)
}

\author{
Ach. Muhib Zainuri ${ }^{1}$, Tundung Subali Patma ${ }^{2}$, Elly Purwanti ${ }^{3}$ \\ 1,2 Jurusan Teknik Mesin, Politeknik Negeri Malang, Jl. Soekarno-Hatta No. 9 Malang \\ ${ }^{3}$ Jurusan Biologi, FKIP, Universitas Muhammadiyah Malang, Jl. Jl. Raya Tlogomas No. 246 Malang \\ "e-mail corresponding author : ${ }^{1}$ muhibzain@gmail.com; \\ e-mail anggota: ${ }^{2}$ subalipatma@yahoo.com; ${ }^{3}$ purwantielly@ymail.com.
}

\begin{abstract}
ABSTRAK
Tujuan yang hendak dicapai dari kegiatan pengabdian masyarakat ini adalah untuk merancang strategi pengembangan wisata kesehatan yang mengombinasikan aspek ekonomi, sosial, dan ekologi dalam pengembangan kepariwisataan di Pulau Giliyang, Kecamatan Dungkek, Kabupaten Sumenep. Untuk mencapai tujuan ini, masalah yang nampak adalah lemahnya institusi pariwisata dan sumberdaya manusia. Metodologi yang digunakan dalam kegiatan ini adalah melalui diskusi kelompok fokus, analisis kebutuhan seluruh pemangku kepentingan, dan mengembangkan pendekatan sistem melalui wawancara mendalam dengan semua pemangku kepentingan. Hasil kegiatan pengabdian kepada masyarakat ini adalah (1) pemberdayaan kelompok sadar wisata Pokdarwis Sora Laksana, (2) penerapan dan pelatihan teknologi tepat guna, dan (3) konservasi hutan mangrove dan hutan pantai. Dampak kegiatan seperti konservasi, pemeliharaan, dan kenyamanan pengunjung menunjukkan nilai positif. Sedangkan pengaruh terhadap perekonomian lokal dan pemberdayaan masyarakat belum menunjukkan nilai positif. Hal ini terjadi karena zonasi wisata masih baru. Sehingga masih dibutuhkan cara yang strategis untuk mencapai pengembangan pariwisata kesehatan yang berkelanjutan.
\end{abstract}

Kata kunci : wisata kesehatan; daya dukung; tata ruang; wisata berkelanjutan; pemberdayaan.

\begin{abstract}
The objective of this community services is to design strategy of health tourism which combines economic, social, and ecological values in tourism development at Giliyang Island - subdistrict Dungkek, Sumenep regency. The problem that faced to achieve the objective are the weakness of institutions and human resources. The methodology used in this activity are focus group discussion (FGD) and stakeholder need analysis (SNA) and system approach that develop from questioners and deep interviews with all stakeholders. The result of community services are (1) empowerment tourism awarness group of Sora Laksana, (2) practice and training of a appropriate technology, and (3) conservation of mangrove and coast forest. Impact of the activities show that such as preservation, conservation, and tourist satisfaction indicate positive value. Meanwhile impact on local economy and community empowerment have not been shown positive value.
\end{abstract}

Cara Mengutip : Zainuri, A.M., Patma, T.S., Purwanti, E. (2020). Strategi Pengembangan Wisata Kesehatan melalui Pemberdayaan Kelompok Sadar Wisata pada Masyarakat Kepulauan (Studi Kasus: Pulau Giliyang Kecamatan Dungkek Kabupaten Sumenep). JAST: Jurnal Aplikasi Sains dan Teknologi, 4 (1), 26-37. doi:http://dx.doi.org/10.33366/jast.v4i1.1547

\section{cc) (i) ()}

BY SA Content from this work may be used under the terms of the Creative Commons AttributionShareAlike 4.0 International License. Any further distribution of this work must maintain attribution to the author(s) and the title of the work, journal citation and DOI. 
These phenomenous happen because the tourism zone still under development.Therefore there is need a strategic strategy to achieve sustainable development of health tourism.

Keywords : health tourism; support capability; lay-out; sustainable tourism; empowerment

\section{PENDAHULUAN}

Saat ini terlihat adanya perubahan minat berwisata dari wisata massal (mass tourism) yang mengandalkan 5S (sun, sea, sand, scenery, dan sex) mengarah pada wisata berwawasan lingkungan (environmentally sound tourism) dan wisata yang berkelanjutan (sustainable tourism). Hal ini ditunjukkan dengan berubahnya pangsa pasar wisata internasional yang mengarah pada kegiatan wisata berwawasan lingkungan pada kawasan wisata alam Afrika dan Asia Pasifik [1]. Perubahan tersebut sebagai akibat overvisitation pada kawasan wisata yang telah dikenal sebelumnya. Keadaan ini juga diakibatkan oleh munculnya kejenuhan wisatawan untuk mengunjungi kawasan wisata buatan (artificial tourism zone) yang mengubah lansekap alam dan merusak lingkungan alamiah.

Perubahan kecenderungan minat wisata dunia tersebut melahirkan konsep baru berwisata yang dikenal dengan wisata kesehatan (health tourism), yang terkait dengan aktivitas perjalanan ke daerah wisata dengan tujuan memperoleh pengobatan atau meningkatkan kesehatan dan kebugaran [2].

Wisata kesehatan adalah bentuk integrasi antara atraksi, akomodasi, dan fasilitas pendukung dalam suatu struktur kehidupan masyarakat yang menyatu dengan tata cara dan tradisi yang berlaku [3]. Tujuan pengembangan wisata kese- hatan di Pulau Giliyang adalah untuk (1) meningkatkan posisi dan peran masyarakat lokal sebagai subjek atau pelaku dalam pembangunan kepariwisataan, (2) membangun dan menumbuhkan sikap dan dukungan positif masyarakat lokal sebagai tuan rumah bagi tumbuh dan berkembangnya wisata kesehatan, (3) masyarakat lokal dapat bersinergi dan bermitra dengan pemangku kepentingan terkait dalam meningkatkan kualitas perkembangan kepariwisataan dan manfaatnya bagi pembangunan maupun kesejahteraan masyarakat di daerah, dan (4) memperkenalkan, melestarikan, dan memanfaatkan potensi daya tarik wisata yang ada. Strategi pengembangan wisata kesehatan di Pulau Giliyang dilakukan melalui pemberdayaan kelompok sadar wisata (Pokdarwis) Sora Laksana yang ada di Pulau Giliyang.

Secara geografis Pulau Giliyang terletak di sebelah timur Pulau Madura, tepatnya di Selat Sapudi pada koordinat $6,96^{\circ}-7,01^{\circ} \operatorname{LS} \& 144,15^{\circ}-114,19^{\circ} \mathrm{BT}$ [4]. Pulau Giliyang adalah sebuah pulau kecil di antara gugusan pulau-pulau di sebelah timur Pulau Madura. Secara administratif, Pulau Giliyang termasuk wilayah Kec. Dungkek, Kab. Sumenep, Jawa Timur. Pulau dengan luas 9,21 km² (921.2 ha) terdiri dari 2 desa, yakni Desa Banraas dan Desa Bancamara [5]. Untuk mencapai lokasi ditempuh dengan perjalanan laut dari Pelabuhan Dungkek menggunakan perahu motor milik nelayan setempat yang melayani pelayaran menuju 
Giliyang menuju dermaga Bancamara. Jarak tempuh mencapai 2,41 mil laut dengan waktu tempuh \pm 30 menit [6].

Mengacu pada hasil pengukuran dari (1) tim Pusat Pemanfaatan Sains Atmosfer dan Iklim dari LAPAN pada 2006, (2) Balai Besar Teknis Kesehatan Lingkungan dan Pengendalian Penyakit (BBTKLPP) Jatim pada 2012, dan (3) BLH \& Bappeda Kab. Sumenep dan Prop. Jawa Timur pada 2014 diketahui konsentrasi oksigen di Pulau Giliyang sebesar 21,5\% dan $\mathrm{CO}_{2}$ mencapai 265 ppm jauh di bawah ambang batas 387 ppm [7]. Dengan kadar oksigen di atas baku mutu normal sehingga bagus untuk kesehatan dan bermanfaat untuk jenis terapi: climatotherapy, thallasotherapy dan heliotheraphy.

Kehadiran ekowisatawan ke tempattempat yang masih alami ini memberikan peluang bagi penduduk lokal untuk memperoleh penghasilan alternatif. Misalnya, menjadi pemandu wisata, membuka homestay atau eco-lodge (pondok wisata), warung dan usaha-usaha lain yang berkaitan dengan wisata. Peluang usaha ini dapat meningkatkan kesejahteraan atau kualitas hidup mereka baik materiil dan spirituil maupun kultural dan intelektual. Di samping berbagai dampak yang dinilai positif, terdapat pula dampak yang tidak diharapkan. Misalnya, kekuatiran rusaknya lingkungan hidup oleh pembangunan pariwisata yang eksploitatif terhadap sumber daya alam, kesenjangan pendapatan antar kelompok masyarakat, dan timbulnya ketimpangan ekonomi akibat akses yang tidak sama terhadap sumber daya alam.

\section{METODE KEGIATAN}

Kegiatan PPM skim PKW Kec. Dungkek ini bertujuan untuk menjabarkan berbagai langkah terkait pengembangan kawasan wisata kesehatan. Hal ini dilakukan untuk menghindari konflik kepentingan antar pemangku kepentingan (stakeholder) dan menjamin keberlanjutan Pulau Giliyang sebagai destinasi wisata kesehatan di Kec. Dungkek - Kab. Sumenep.

Kegiatan PPM skim PKW ini secara umum bertujuan untuk mengembangkan wisata kesehatan melalui pemberdayaan kelompok sadar wisata "Sora Laksana" (Pokdarwis Sora Laksana) di Pulau Giliyang. Model pengembangan wisata kesehatan melalui pemberdayaan Pokdarwis yang diterapkan didasarkan atas kebutuhan, potensi, harapan, budaya, serta kearifan lokal masyarakat Giliyang.

Model pengembangan wisata kesehatan ini melibatkan 5 (lima) aspek, yaitu: (1) Aspek ekonomi, tentang peningkatan pendapatan masyarakat yang sebagian besar sebagai nelayan, (2) Aspek pendidikan, berupa peningkatan keterampilan melalui difusi iptek; (3) Aspek lingkungan dan kesehatan, terdiri atas konservasi mangrove dan hutan pantai; (4) Aspek infrastruktur, berupa revitalisasi homestay; dan (5) Aspek sosial budaya, yaitu menumbuh kembangkan sifat gotong-royong serta iman dan taqwa masyarakat Giliyang sebagai norma yang menjaga ekses negatif pariwisata [8].

Untuk menentukan tujuan strategis dan kepentingan stakeholder, Tim PPM skim PKW di Kec. Dungkek telah melakukan tahap kegiatan sebagai berikut. 
- Focus group discussion (FGD)

FGD dilaksanakan untuk mendapatkan pendapat dan masukan secara intensif dari stakeholder yang terkait dengan pengembangan kawasan (gbr. 1);

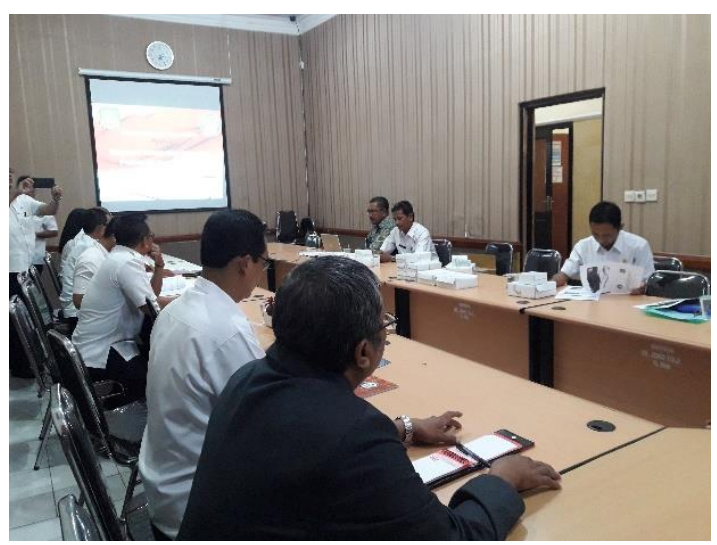

Gambar 1. FGD dengan Bappeda dan Dinas terkait di Kab. Sumenep

\section{- Pendidikan Masyarakat}

Berupa penyuluhan untuk meningkatkan pemahaman pentingnya ekosistem mangrove dan hutan pantai bagi keberlanjutan pemanfaatan SDA yang lestari (gbr. 2);

\section{○ Difusi Ipteks}

Salah satu kondisi yang dialami pelaku usaha bidang kelautan dan perikanan di Pulau Giliyang adalah lemahnya pemanfaatan iptek dalam produksinya. Kegiatan PPM skim PKW menghasilkan beberapa produk TTG (gbr. 3) yang akan dihibahkan kepada pelaku usaha melalui Pokdarwis Sora Laksana.

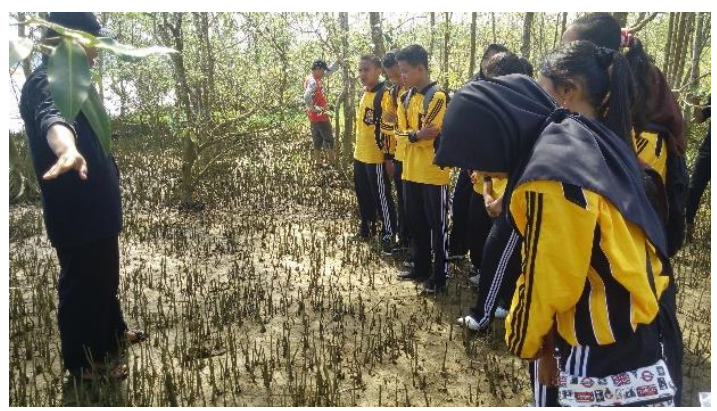

Gambar 2. Penyuluhan fungsi mang-rove dan hutan pantai
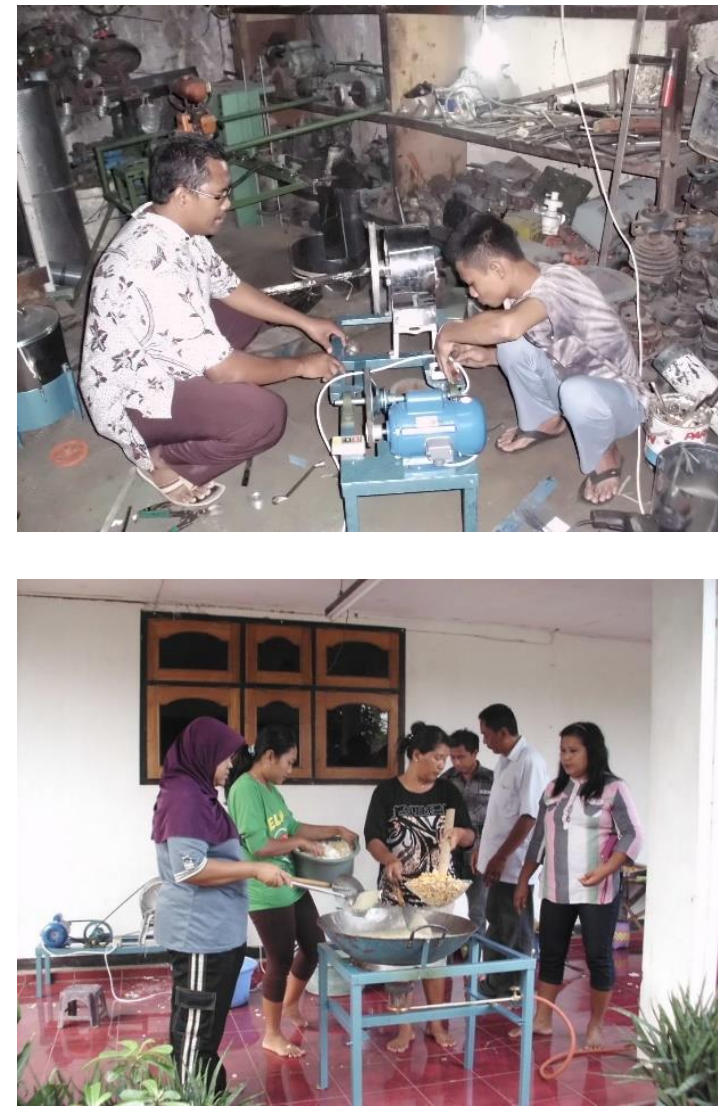

Gambar 3. Rancang bangun dan pelatihan produk TTG bidang perikanan

\section{- Pelatihan}

Kegiatan pelatihan meliputi usaha berbasis komoditas ikan hasil penangkapan di laut, pengolahan dan penyuluhan. Pembinaan teknis meliputi diversifikasi produk, manajemen finansial, dan strategi pemasarannya.

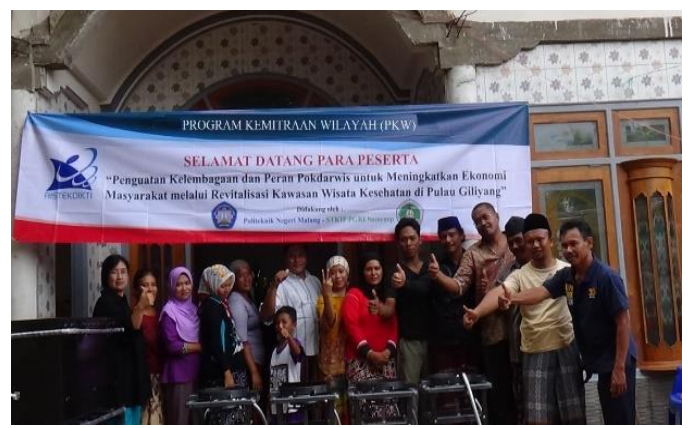

Gambar 4. Pelatihan produk TTG oleh Tim PKW di Pulau Giliyang 


\section{KARYA UTAMA}

Untuk mengembangkan kawasan Pulau Giliyang sebagai destinasi wisata kesehatan, tim PPM skim PKW bersama dengan Pokdarwis Sora Laksana telah melakukan beberapa kegiatan. Hal ini dilakukan untuk perlindungan terhadap kelestarian lingkungan dan budaya setempat, kontribusi ekonomi lokal, dan pemberdayaan masyarakat setempat.

\subsection{Konservasi Ekosistem Mangrove}

Hutan mangrove berperan besar dalam mitigasi dampak perubahan iklim gobal (climate change) dan efektif menurunkan emisi gas karbon [9]. Karena fungsi dan manfaatnya yang besar, mangrove perlu dilestarikan. Melalui konservasi mangrove, Tim PPM skim PKW di Pulau Giliyang, Kec. Dungkek Kab. Sumenep melakukan penanaman bibit mangrove, khususnya di kawasan hutan mangrove desa Banraas (gbr. 5).

Bentuk kegiatan, berupa (a) Sosialisasi dan edukasi mangrove, (b) penanaman bibit mangrove, dan (c) pemantauan tumbuh kembang mangrove. Tujuannya adalah: (a) mensosialisasikan mangrove di kalangan generasi muda, (b) memberikan edukasi dan kesadaran akan pentingnya pelestarian hutan mangrove dalam memitigasi dampak bencana perubahan iklim dan pemanasan global, (c) membangun kerjasama, kepedulian, dan tanggung jawab sosial secara individu dan kelompok, dan (d) mendar-mabaktikan kemampuan intelektual, pikiran, dan tenaga untuk kepentingan masyarakat pada masa depan.

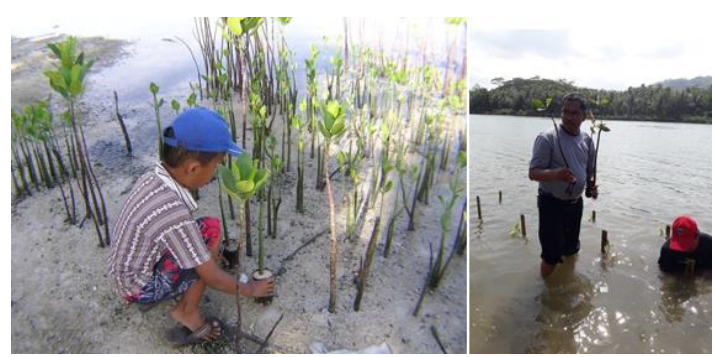

Gambar 5. Pembibitan vegetasi tanaman dan penanaman tumbuhan mangrove

\subsection{Konservasi Hutan Pantai}

Hutan pantai memberikan perlindungan terhadap badai, angin, terpaan garam, meningkatkan keragaman hayati dari lingkungan pantai, serta memberikan perlindungan terhadap tsunami [10]. Saat ini, penggunaan lahan di pesisir pantai lebih digunakan untuk pengambilan pasirnya. Hal ini karena pasir pantai lebih memberikan keuntungan jangka pendek.

Beberapa kegiatan telah dilakukan tim PKW Kec. Dungkek - Kab. Sumenep untuk konservasi ekosistem hutan pantai. Tahapannya meliputi: (1) Persiapan dan survei, (2) Rehabilitasi dan konservasi, dan (3) Pemeliharaan dan monitoring. Jenis vegetasi pantai yang ditanam: Pohon bakau (Rhizopora mucronata), Ketepeng (Terminalia catapa), Waru (Hibiscus tiliaceus), pandan (Pandanus tectorius), Keben (Baringtonia $s p$ ), dan kelapa (gbr. 6 ).

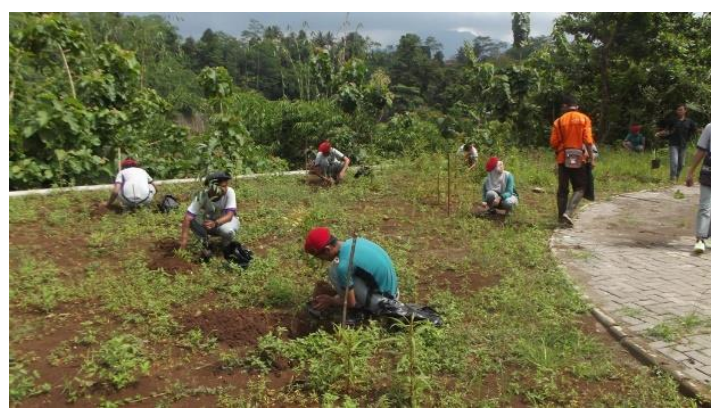

Gambar 6. Penanaman tumbuhan vegetasi hutan pantai 


\subsection{Revitalisasi Infrastruktur Wisata}

Kawasan wisata seharusnya memiliki beberapa unsur penting, yaitu: daya tarik, infrastruktur wisata, masyarakat, lingkungan, dan budaya. Infrastruktur adalah situasi yang mendukung fungsi sarana dan prasarana wisata kesehatan, misalnya bangunan fisik homestay. Infrastruktur yang memadai akan membantu meningkatkan fungsi kawasan wisata, sekaligus membantu masyarakat meningkatkan kualitas hidupnya melalui kegiatan pariwisata [11].

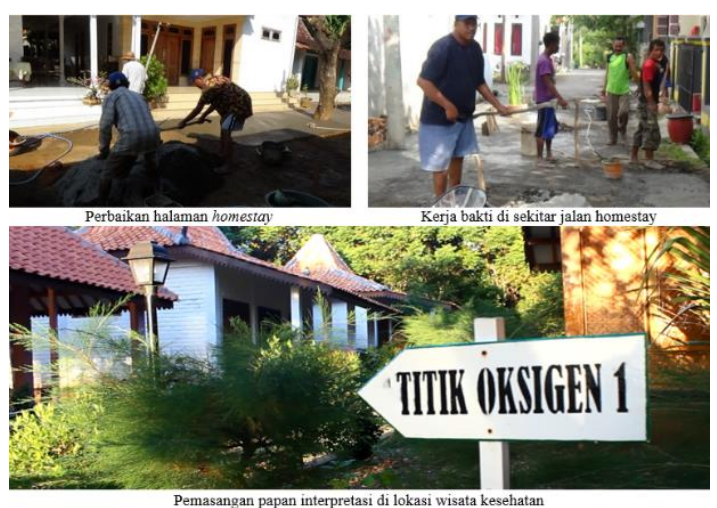

Gambar 7. Revitalisasi homestay di Pulau Giliyang

Tim PPM skim PKW Kec. Dungkek telah merevitalisasi homestay yang ada di Desa Banraas (gbr. 7). Tujuannya agar ekowisatawan memiliki pilihan bermalam saat melakukan kunjungan wisata ke Pulau Giliyang bersama keluarga dan koleganya.

\subsection{Pembangunan Prototype PLTS}

Pemanfaatan sumber energi terbarukan bisa menjadi alternatif pengadaan energi listrik di Pulau Giliyang. Energi terbarukan yang bersumber dari sinar matahari sangat tepat diterapkan di desa Bancamara dan Desa Banraas. Instalasi sumber energi matahari (solar cell) bisa diterapkan pada masing-masing rumah tangga. Tim PPM skim PKW di Kec. Dungkek telah membuat prototype instalasi pembangkit listrik tenaga surya (PLTS). Sebagai prototype, telah dibuat 2 unit masing-masing dengan kapasitas 100 watt peak (WP) untuk penerangan jalan dan kebutuhan listrik di TPQ. Ar-Rohman hybrid dengan genset (gbr. 8).

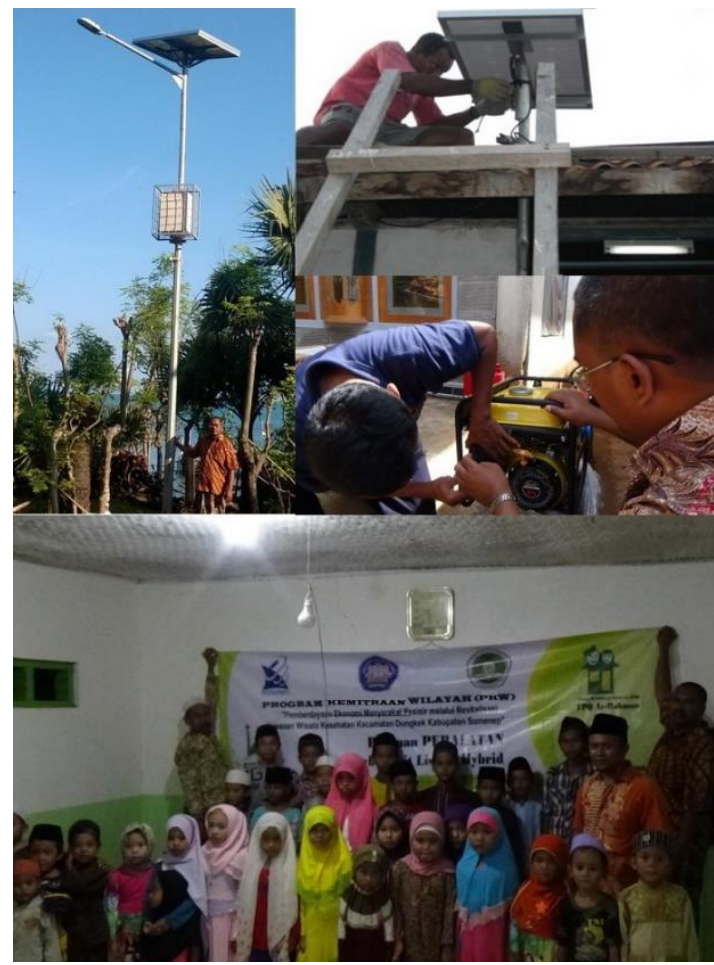

Gambar 8. Pemanfaatan PLTS hybrid genset sebagai sumber energi listrik

\subsection{Penguatan Usaha Minabisnis}

Masyarakat Pulau Giliyang sebagian besar berprofesi sebagai nelayan perikanan tangkap. Profesi ini menjadi sumber mata pencaharian, terutama nelayan, pengolah hasil perikanan, dan pedagang ikan [12]. Di samping itu juga berfungsi sebagai penyedia sumber protein ikan bagi masyarakat.

Sebagai salah satu wilayah potensial penghasil produk laut di Kab. Sumenep, menjadikan perikanan sebagai sektor penting pembangunan wilayah di Pulau Giliyang. Potensi bahari disinergikan 
dengan kegiatan pariwisata. Tim PPM skim PKW melihat potensi ini dapat menjadi sumber kekuatan ekonomi masyarakat lokal.

Ikan hasil tangkapan yang menjadi sumber pendapatan penting bagi keluarga nelayan, umumnya dijual dalam bentuk ikan segar [13]. Hanya sedikit yang memanfaatkan ikan tersebut sebagai bahan baku olahan. Kalaupun ada, kegiatan proses pengolahan ikan masih dilakukan secara tradisional [14]. Dari gambaran kegiatan ekonomi berbasis ikan laut di Pulau Giliyang, terbuka peluang pemanfaatan teknologi tepat guna (TTG), baik untuk meningkatkan mutu produk, maupun penganekaragaman jenis olahan. Diharapkan, melalui penerapan TTG, peluang untuk pengembangan minabisnis berbasis olahan hasil laut semakin terbuka [15].

Usaha mendorong produktivitas dan tumbuhnya usaha minabisnis, Tim PPM skim PKW Kec. Dungkek telah membuat beberapa prasarana produksi. Prasarana tersebut dikembangkan sesuai dengan kebutuhan pasar, mudah dioperasikan, dan suku cadangnya mudah diperoleh di pasar lokal. Prasarana tersebut adalah: oven berbahan bakar LPG, mesin pengasap ikan (smoked fish) berbahan bakar arang kayu, mesin penggorengan deep fat frying berbahan bakar LPG. Telah dilakukan kegiatan aksi penerapan TTG aneka olahan hasil laut, yaitu: (a) produksi abon ikan, crispy ikan, dendeng dan krupuk ikan menggunakan deep fat frying, (b) produksi kue menggunakan oven, (c) produksi ikan asap menggunakan smoked fish. Hal ini dilakukan kepada beberapa usaha kelompok skala rumah tangga mitra kerja binaan bersama dengan Bappeda Kab. Sumenep (gbr. 9).

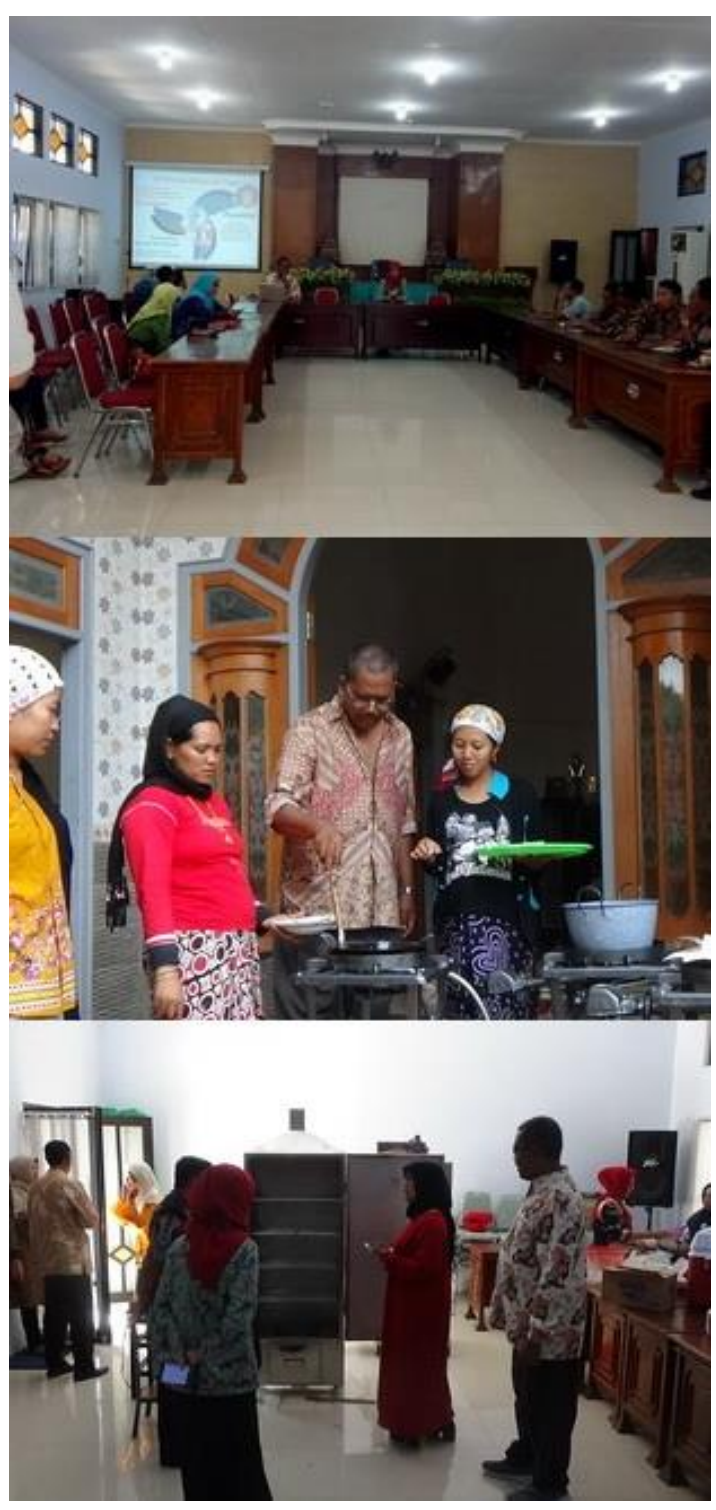

Gambar 9. Pelatihan TTG untuk penguatan minabisnis

\section{ULASAN KARYA}

Pulau Giliyang adalah salah satu di antara total 126 pulau di Kab. Sumenep. Secara administratif, Pulau Giliyang termasuk wilayah Kec. Dungkek, Kab. Sumenep, Jawa Timur [15]. Untuk mencapai lokasi ditempuh dengan perjalanan laut dari Pelabuhan Dungkek menggunakan perahu motor milik nelayan 
yang melayani pelayaran menuju Giliyang ke dermaga Bancamara.

Perairan Pulau Giliyang berbatasan langsung dengan Laut Jawa memiliki dasar perairan berkarang dengan ombak sedang. Dengan panjang pantai $14 \mathrm{~km}$ merupakan habitat terbangunnya komunitas mangrove. Variasi substratnya di sepanjang pantai memungkinkan adanya keragaman jenis yang tinggi baik dilihat sebagai sebuah tipe ekosistem ataupun tipe vegetasi. Dari berbagai variasi topografi serta posisinya dari muka laut yang ada sehingga menyebabkan variasi intensitas genangan, variasi pengaruh salinitas di berbagai lokasi secara kompleks juga membentuk sejumlah kondisi spesifik yang berbeda. Sehingga pada akhirnya dapat dilihat sebagai sebuah kekhasan mangrove di Pulau Giliyang.

Ekosistem hutan mangrove mengandung potensi besar memenuhi kebutuhan hidup dan sinergisme dengan aktifitas wisata di Pulau Giliyang. Spesifikasi jenis mangrove yang sebagian besar didominasi dari jenis sentigi menjaga kandungan $\mathrm{O}_{2}$ yang tinggi di Pulau Giliyang. Tim PPM skim PKW bersama dengan Pokdarwis Sora Laksana telah melakukan konservasi hutan mangrove (gbr. 5) berupa penanaman tumbuhan mangrove yang terdiri dari Bakau (Rhizopora mucronata), Apiapi (Avicenna alba), Cemara laut (Casuarina equisetifolia), dan Sentigi (Phemphis acidula). Khusus pohon Sentigi, merupa-kan salah satu spesies pohon mangrove langka yang sangat bermanfaat untuk menjaga keseimbangan ekosistem di daerah pantai. Jenis ini merupakan jenis tumbuhan potensial dan marak untuk dijadikan sebagai bonsai, gelang, tasbih maupun kerajinan ukir yang lain.

Pantai di Pulau Giliyang termasuk jenis pantai berpasir halus. Pantai berpasir dicirikan oleh ukuran butiran sedimen halus dan memiliki tingkat bahan organik yang tinggi. Hutan pantai memberikan perlindungan terhadap badai, angin, terpaan garam, meningkatkan keragaman hayati dari lingkungan pantai, dan memberikan perlindungan terhadap bahaya tsunami. Selain itu, hutan pantai memberikan kesempatan peningkatan produktifitas dari sistem perikanan, serta memasok kayu dan produk hutan nonkayu.

Pemkab Sumenep melaksanakan program kelistrikan di Pulau Giliyang secara terbatas. Hal ini atas rekomendasi Lembaga Penerbangan dan Antariksa Nasional (LAPAN) untuk menjaga kualitas oksigen di pulau tersebut [16]. Pembangkit Listrik Tenaga Diesel (PLTD) hanya dioperasikan di malam hari sambil mencari bentuk sumber energi lain yang sesuai dan tidak merusak kualitas oksigen di Pulau Giliyang yang dinilai salah satu terbaik di dunia. Pemanfaatan sumber energi terbarukan menjadi alternatif pengadaan energi listrik di Pulau Giliyang. Energi terbarukan solar cell sangat tepat diterapkan di pulau ini sebagaimana yang dilakukan oleh tim PPM skim PKW (gbr. 8).

Pemanfaatan dan pengelolaan sumberdaya perikanan tangkap dilakukan berdasarkan prinsip pembangunan berkelanjutan (sustainable development). Dalam prinsip ini, pemanfaatan dan pengelolaan sumberdaya perikanan mempertimbang- 
kan beberapa aspek penting, yaitu: aspek ekologi, sosial, dan ekonomi.

Dari aspek ekologi, pemanfaatannya menggunakan teknologi yang bersifat ramah lingkungan. Sementara dari aspek ekonomi, pemanfaatan sumberdaya perikanan menghasilkan nilai ekonomi terhadap pengguna sebagai sumber penghasilan. Kemudian, dari aspek sosial, pemanfaatan dan pengelolaan yang dilakukan terhadap sumberdaya perikanan tersebut dapat diterima masyarakat yang berkepentingan (stakeholders). Ketiga aspek tersebut terbentuk dalam suatu kerangka pengelolaan sumberdaya perikanan dalam suatu kelembagaan Pokdarwis Sora Laksana.

\section{DAMPAK DAN MANFAAT KEGIATAN}

Derap langkah kehidupan masyarakat pesisir Pulau Giliyang akhir-akhir ini semakin meningkat. Peningkatan tersebut seiring berkembangnya kegiatan perekonomian dan pembangunan pariwisata di wilayah tersebut. Namun demikian, perkembangan tersebut dapat menimbulkan dampak, baik yang negatif maupun yang positif. Sebelumnya, marak pengambilan pasir pantai untuk berbagai kegiatan. Tim PPM skim PKW Kec. Dungkek bersama dengan Pokdarwis Sora Laksana telah melakukan pendekatan yang dapat mengakomodir berbagai kegiatan yang berbeda tersebut.

Program pengelolaan sumberdaya alam yang berwawasan lingkungan [17] diharapkan dapat bersinergi dengan pengembangan sektor pariwisata di Pulau Giliyang. Manfaat kegiatan, yaitu: (a) mendukung upaya mitigasi dampak perubahan iklim dunia, (b) mendukung program pemerintah dalam melestarikan mangrove dan hutan pantai , (c) menciptakan lingkungan hijau dan berdaya guna di kawasan, dan (d) memberdayakan masyarakat melalui pelatihan pengolahan hasil mangrove pada masa mendatang.

Lingkungan biofisik obyek wisata terdiri dari berbagai macam komponen biologik dan fisik yang saling berinteraksi satu sama lain. Komponen biologik misalnya flora dan fauna. Komponen fisik misalnya topografi, keadaan tanah, iklim, sarana dan prasarana, luas efektif kawasan wisata, petugas pelayanan wisata (dalam hal ini Pokdarwis), waktu yang dibutuhkan wisatawan untuk melakukan aktivitas wisata dan ruang gerak wisatawan.

Karakteristik lanskap kawasan Pulau Giliyang sangat unik karena mem-punyai tiga karakteristik utama, yaitu: pantai landai dengan tebing-tebing bibir pantai yang terdapat juntaian pohon Sentigi, terdapat banyak gua, dan dataran rendah. Ketiganya terintegrasi menjadi satu membentuk kawasan pantai yang menarik untuk dikunjungi. Tersedia fasilitas homestay baik yang dibangun Pemkab Sumenep maupun penginapan yang dikelola masyarakat.

Tim PPM skim PKW Kec. Dungkek bersama dengan Pokdarwis Sora Laksana telah merevitalisasi infrastruktur wisata, yaitu homestay dan penerangan dengan membangun 2 buah PLTS 100 WP hybrid dengan genset. Manfaat kegiatan adalah (1) menciptakan kesempatan pendidikan dan pelatihan bagi masyarakat lokal; (2) mendukung lembaga masyarakat; (3) meningkatkan pengembangan individu dalam mengurangi arus urbanisasi ke 
kota; (4) meningkatkan nilai tambah untuk budaya dan tradisi lokal; dan (5) menyediakan keuntungan infrastruktur.

Industrialisasi perikanan merupakan program pembangunan sektor perikanan yang mendukung pelaksanaan program minapolitan [18]. Penerapan industrialisasi perikanan yang dilakukan oleh Tim PPM skim PKW di Kec. Dungkek fokus pada penguatan usaha minabisnis diharapkan memberi manfaat dan dampak yang maksimal bagi pengembangan ekonomi dan peningkatan pendapatan masyarakat di Pulau Giliyang. Manfaat kegiatan adalah (1) menciptakan kesempatan dan pekerjaan dengan kegiatan pengolahan produk perikanan tangkap dengan tidak mengubah kegiatan ekonomi yang sudah ada; (2) menciptakan hubungan ekonomi antar sektor khususnya dengan pariwisata; (3) sinergi wisata kesehatan dan minabisnis untuk menyediakan pasar promosi barang dan jasa; (4) berkontribusi untuk pembangunan yang seimbang; (5) memanfaatkan sumber daya alam secara berkelanjutan, tetapi tidak mengeksploitasi; (6) memperkecil dampak lingkungan; dan (7) mendorong masyarakat agar tidak konsumtif dalam menggunakan sumber daya.

\section{KESIMPULAN}

Kawasan pesisir dengan keanekaragaman hayatinya jika dikelola dengan baik bisa menjadi pusat pertumbuhan ekonomi dan pendorong peningkatan kesejahteraan masyarakat. Salah satu usaha yang dapat dilakukan adalah dengan mengembangkan pariwisata. Untuk itu, sinergitas antara perguruan tinggi, pelaku usaha, dan lembaga pemerintah (A-B-G, academic-business-government), serta Pokdarwis menjadi salah satu kunci keberhasilan pengembangan kawasan wisata kesehatan di Pulau Giliyang.

Keberadaan institusi Pokdarwis Sora Laksana menjadi hal penting dalam pengembangan wisata kesehatan di Pulau Giliyang. Pokdarwis membantu program PPM skim PKW untuk mengetahui kondisi, kebutuhan, permasalahan, dan harapan yang dimilikinya secara bebas. Selanjutnya, melalui wawancara mendalam ditentukan langkah apa yang mesti dilakukan untuk mengatasi permasalahan tersebut.

Program PPM skim PKW di Pulau Giliyang, Kec. Dungkek - Kab. Sumenep, yaitu: (1) konservasi ekosistem mangrove, (2) konservasi hutan pantai, (3) revitalisasi infrastruktur wisata, (4) pembangunan prototype PLTS hybrid genset, dan (5) penguatan usaha minabisnis. Program ini dilakukan dengan mengedepankan konsep partisipai setelah melalui diskusi kelompok fokus (FGD) dan analisis kebutuhan seluruh pemangku kepentingan.

Banyak hal yang menjadi kendala dalam pengembangan kawasan Pulau Giliyang sebagai destinasi wisata kesehatan di Kab. Sumenep. Akan tetapi hal ini masih dapat dikatakan berada pada taraf wajar karena fenomena ini terjadi karena zonasi wisata masih baru. Sehingga masih dibutuhkan strategi yang strategis untuk mencapai pengembangan pariwisata yang berkelanjutan. Oleh karena itu, program PPM skim PKW di Pulau Giliyang pada tahun berikutnya adalah (1) pembangunan objek wisata kesehatan dan (2) revitalisasi kawasan Giliyang. 


\section{PENGHARGAAN}

Atas pelaksanaan PPM skim PKW di Pulau Giliyang, Kec. Dungkek, Kab. Sumenep pada tahun I, tim pengabdi menyampaikan terima kasih kepada beberapa pihak yang membantu kelancaran kegiatan ini. Ucapan terima kasih disampaikan kepada:

1. DRPM, Ditjen Risbang, Kemristekdikti, Jakarta beserta seluruh jajarannya;

2. Bappeda Kab. Sumenep dan Camat Dungkek beserta segenap jajarannya yang telah ikut membantu kelancaran pelaksanaan kegiatan PPM skim PKW;

3. Direktur Politeknik Negeri Malang dan DRPM UMM yang membantu kemudahan bagi terlaksananya kegiatan PPM skim PKW;

4. Unit Pelaksana Teknis Penelitian dan pengabdian Kepada Masyarakat, Politeknik Negeri Malang (UPT. P2M Polinema) yang telah membantu kelancaran administrasi pelaksanaan PPM skim PKW; dan

5. Ketua Jurusan Teknik Mesin Politeknik Negeri Malang beserta segenap jajarannya yang telah membantu ijin pemakaian bengkel dalam pembuatan alat.

\section{DAFTAR PUSTAKA}

[1] Dirawan, G.D. dan Darmawan, M.R. 2006. Pola Dasar Pengembangan Pariwisata Kabupaten Daerah Tingkat II Polewali Mandar, Laporan Proyek Kerjasama Dinas Pariwisata Kab. Polmas dan Universitas Negeri Makassar, Polewali.

[2] Inskeep, E. 1991. Tourism Planning an Integrated Sustainable Development
Approach, Van Notrand Reinhold, New York.

[3] Nuryanti, Wiendu. 1993. Concept, Perspective and Chalenges in Ecotourism, makalah pada Konferensi Internasional mengenal Pariwisata Budaya, Gadjah Mada University Press, Yogjakarta, 1993.

[4] Badan Pusat Statistik Kabupaten Sumenep, 2015, Kabupaten dalam Angka, ISSN: 0215.5710, Katalog BPS : 1102001.3501.

[5] Pemerintah Kabupaten Sumenep, 2015, Rencana Pembangunan Jangka Menengah Daerah Tahun 2015 - 2020, Peraturan Daerah Kabupaten Sumenep No. 10 Tahun 2011;

[6] Badan Pusat Statistik Kabupaten Sumenep, 2015, Kecamatan Dungkek dalam Angka 2015, Nomor Katalog: 1102001.3501110;

[7] Dinas Kebudayaan, Pariwisata, Pemuda dan Olaraga Kab. Sumenep, 2015, Daya Tarik Wisata Kab. Sumenep, booklet yang diterbitkan oleh Dinas Kebudayaan dan Pariwisata Provinsi Jawa Timur.

[8] Badan Pembangunan dan Perencanaan Daerah Kabupaten Sumenep, 2014, Masterplan Minapolitan Kabupaten Sumenep;

[9] Wiyono, Maridi, 2009, Pengelolaan Hutan Mangrove dan Daya Tariknya sebagai Objek Wisata di Kab. Sumenep, Jurnal Aplikasi Manajemen, Vol. 7, No. 2, Mei 2009, ISSN : 16935241.

[10] Umar, Muhammad Zulkarnain. 2013. Strategi Untuk Mengembangkan Pantai Sebanjar Sebagai Objek Pariwisata Unggulan di Kabupaten Alor Propinsi 
NTT. Tugas Akhir. Program Studi Perencanaan Wilayah dan Kota, Fakultas Teknik, Universitas Islam Bandung.

[11] Badan Pembangunan dan Perencanaan Daerah Kabupaten Sumenep, 2015, Rencana Tata Ruang Wilayah Kabupaten Sumenep;

[11] Pemerintah Kab. Sumenep, 2013, Profil Dinas Kelautan dan Perikanan, http://www.dkp.Sumenepkota.go.id.

[12] Pemerintah Kab. Sumenep, 2013, Profil Dinas Kelautan dan Perikanan, http://www.dkp.Sumenepkota.go.id.

[13] Kementerian Kelautan dan Perikanan, 2013, Pengembangan Kawasan Minapolitan, Sekretariat Jenderal KKP, Jakarta.

[14] Pemerintah Kab. Sumenep, 2010, Profil Kelurahan 2010, Badan Perencanaan Pembangunan Daerah Kab. Sumenep.
[15] Dinas Kelautan dan Perikanan Kabupaten Sumenep, 2014, Profil Potensi Kelautan dan Perikanan Kabupaten Sumenep.

[16] Nota Kesepahaman antara Kementerian Kesehatan RI dan Kementerian Pariwisata dan Ekonomi Kreatif, 2012, tentang Wisata Kesehatan (Health Tourism), No.: 412/Menkes/SKB/ XI/ 2012 dan No.: NK/30/PW.202/ MPEK/2012.

[17] Yulinda, F. 2007. Ekowisata Sebagai Alternatif Pemanfatan Sumberdaya Pesisir Berbasis Konservasi. Bogor. MSP - FPIK IPB.

[18] Zahri Nasution dan Bayu Vita Indah Yanti. 2014. Industrialisasi Perikanan Mendukung Ketahanan Pangan di Pedesaan Perairan Umum Daratan. J. Kebijakan Sosek KP Vol. 4 No. 2 Tahun 2014. 